\title{
Toxic Nitro Compounds in Species of Astragalus (Fabaceae) in Argentina
}

\section{COBURN WILLIAMS AND EDITH GOMEZ-SOSA}

\section{Abstract}

Thirty species of Astragalus from Argentina were analyzed for toxic aliphatic nitro compounds. Twenty-seven species, including 7 species known to poison livestock, synthesized nitro compounds that hydrolyzed to highly toxic 3-nitro-l-propanol (3-NPOH). Nitro compounds in A stragalus palenae (Phil.) Reiche hydrolyzed to both 3-NPOH and 3-nitropropionic acid (3-NPA). Astragalus palenae is the only species of Astragalus so far examined that synthesized both compounds. Analyses of leaves of the 30 species for cyanogenic glycosides were negative. Species of Astragahus from Argentina that synthesize nitro compounds should not be introduced into the United States because of their potential hazard to livestock.

The genus Astragalus consists of over 2,000 species world-wide. Although most species occur in the temperate regions of the Northern Hemisphere, 105 species are indigenous to western and southern South America from Ecuador to Argentina. Sixty-four species are native to Argentina.

Several species of $A$ stragalus are known to poison livestock and have caused losses on rangelands and pastures in Argentina. Gómez-Sosa (1979) reported that Astragalus bergii Hieron., $A$. chamissonis (Vog.) Reiche, A. distinens Macloskie, A. pehuenches Niederl. and $A$. vesiculosus Clos. caused livestock losses in Patagonia (the five southern provinces of Argentina). Monticelli (1938) reported a large loss of animals to Astragalus bergii in 1931 in San Luis Province in central Argentina. Gómez-Sosa was told by farmers in Tucumán Province in northwestern Argentina that Astragalus cryptobotrys Johnst. caused both addiction and death in their livestock. Elsewhere in Argentina, A. garbancillo Cav. has caused livestock losses (Burkart 1952). Astragalus arequipensis Vog. was reported toxic to livestock in Bolivia (Burkart 1952).

Evidence existed that species of Astragalus indigenous to Argentina synthesized highly toxic nitro compounds. Nitro compounds are particularly toxic to ruminants because microflora in the rumen hydrolyze them to 3-nitro-1-propanol (3-NPOH) or 3nitropropionic acid (3-NPA) (Williams et al. 1970, Williams 1982). While both compounds are toxic, animals are poisoned orally at lower concentrations of $3-\mathrm{NPOH}$ because it is more rapidly absorbed into the circulatory system.

Of the species reported poisonous in Patagonia by Gómez-Sosa (1979), Astragalus bergii, $A$. distinens, and $A$. vesiculosus were known to synthesize nitro compounds (Williams 1981) and the latter 2 species synthesized 3-NPOH (Williams 1982). The toxic principle in the other 2 species, $A$. pehuenches and $A$. chamissonis, was unknown. Four other nitro-bearing species of Astragalus also occur in Patagonia: $A$. domeykoanus (Phil.) Reiche, $A$. cruckshanksii (Hook. \& Arn.) Griseb., A. palenae (Phil.) Reiche, and $\boldsymbol{A}$. patagonicus (Phil). Speg. (Gómez-Sosa 1984). These data suggested that nitro compounds might be the toxic principle in other

\footnotetext{
Authors are plant physiologist. USDA-ARS, Poisonous Plant Research Laboratory, 1150 E. 1400 N., Logan, Utah 84321 ; and plant taxonomist, Instituto de Botanica Darwinion, 1642 San Isidro, Buenos Aires, Argentina. The research represents a cooperative investigation by the USDA-ARS, Instituto de Botanica Darwinion and the Utah Agricultural Experiment Station, Logan 84322.

Edith Gómez-Sosa expresses her deep appreciation to Ing. Fidel Roig, Department of Botany IADIZA, Mendoza, and Dr. Stephen Halloy and Lic. Juan González of M. Lillo Institute. Tucumán, for permitting her to accompany them on collecting trips. She also thanks Dr. Juan Hunziker for his support of this project and both Dr. Hunziker and Dr. Robert Kiesling for collecting plants for us. Both authors thank Ing. Hugo Cordo, Biological Control of Weeds Laboratory, USDA-ARS, Buenos Aires, for several specimens of Astragalus used in this study.

This article is published with the approval of the Director, Agricultural Experiment Station, Utah State University as Journal Article No. 3146.

Manuscript accepted 14 November 1985.
}

poisonous species of Astragalus in Argentina.

Cooperative research between personnel at the Instituto de Botanica Darwinion, San Isidro, Argentina, and the Poisonous Plant Research Laboratory, Logan, Utah, was initiated to: determine the presence or absence of aliphatic nitro compounds in species of Astragalus in Argentina; identify the type of nitro compound present; recommend methods to reduce livestock losses from nitro-bearing species; and prevent the exportation of poisonous species of Astragalus which, if introduced or released on grazing lands, might cause livestock losses in other countries.

\section{Methods}

Thirteen species of Astragalus were collected in Argentina in the field during 1984 from the provinces of San Juan and Tucumán and from Mendoza in 1985. San Juan and Mendoza Provinces border Chile in west central Argentina. Plants were in flower to pod stage of growth. Leaves of the remaining species of Astragalus were sampled from herbaria at the Instituto de Botanica Darwinion, San Isidro, Argentina (SI), the National University of La Plata, Argentina (LP), Royal Botanic Gardens, Kew, England (K), The New York Botanical Garden, Bronx, New York, USA (NY), and from specimens at the Biological Control of Weeds Research Laboratory, U.S. Dept. of Agriculture, ARS, Buenos Aires, Argentina. The latter source has been designated as Herbarium Cordo. All species were personally identified by Edith GómezSosa except Astragalus domeykoanus and $A$. micranthellus Wedd. Leaves of these species were sampled at $K$ and NY and the presence of nitro compounds in them was reported previously (Williams 1981, Williams 1982). Samples of the other 34 species of Argentine Astragalus were not available for study. All samples were sent to the Poisonous Plant Research Laboratory, Logan, Utah, for analysis.

Samples were analyzed qualitatively for the presence of nitro compounds (Williams and Barneby 1977), type of nitro compound (Williams 1982), and for cyanogenic glycosides (AOAC 1980). Cyanogenic glycosides were reported in Astragalus in Argentina (Giusti 1938).

Leaves from 3 accessions of Lotus tenuis Waldst. \& Kit. ex Willd. and 1 of $L$. wrightii (A. Gray) Greene collected between 1970 and 1980 were sampled from the Intermountain Herbarium at Utah State University, Logan, Utah, and tested for HCN. These species were known to synthesize cyanogenic glycosides (M.C. Williams, unpubl. data). The Lotus leaves were analyzed for HCN to determine if this compound could be detected in dried leaves that were 5 to 15 years old and might therefore be detected in dried leaves of Astragalus if present.

\section{Results and Discussion}

Twenty-seven species and 1 variety of Astragalus tested positive for nitro compounds (Table 1 ). Only 3 species, $A$. ruiz-lealii Johnst., A. monticola Phil., and $A$. joergensenii Johnst., tested negative. The nitro compounds in all other species yielded 3NPOH upon hydrolysis. The nitro compounds in $A$. palenae yielded both 3-NPOH and 3-NPA. Heretofore, nitro-bearing species of Astragalus examined have synthesized either 3-NPOH or 3-NPA but not mixtures of the two. Astragalus palenae is the first species of Astragalus found to contain both compounds. The origin of the specimen of $A$. domeykoanus sampled at $\mathrm{Kew}$ is 
obscure. However, the species is found throughout Patagonia from the provinces of Neuquén to Santa Cruz.

Qualitative analysis of $A$. bergii and $A$. distinens yielded a nitro content of approximately $9 \mathrm{mg} \mathrm{NO} / \mathrm{g}$ of leaf. Quantitative analysis of leaves of 1 sample of $A$. vesiculosus yielded $9.2 \mathrm{mg} \mathrm{NO} / \mathrm{g}$. The concentration of 3-NPOH in these species was equal to that found in A. emoryanus var. emoryanus (Rydb.) Cory which caused devastating losses in cattle and sheep in New Mexico in 1975 (Williams et al. 1979). A. palenae contained the same amount of
$\mathrm{NO}_{2}$, but as a mixture of 3-NPOH and 3-NPA.

All Lotus species tested positive for HCN. Analyses for $\mathrm{HCN}$ in the Argentine species of Astragalus tested in this study were all negative. Cyanogenic glycosides have not previously been implicated as toxic compounds in the genus Astragalus.

Cyanogenic glycosides, saponins, and selenium have been suggested as the toxic principle in Argentine species of Astragalus. Giusti (1938) found cyanogenic glycosides in Astragalus bergii. Awschalom (1928) extracted saponins from Astragalus garban-

Table 1. Presence and type of nitro compound in species of Astragalus in Argentina.

\begin{tabular}{|c|c|c|c|c|c|c|}
\hline Astragalus species & $\begin{array}{l}\text { Qualitative } \\
\text { analysis } 1\end{array}$ & $\begin{array}{c}\text { Nitro } \\
\text { compound }\end{array}$ & $\begin{array}{l}\text { Voucher } \\
\text { number }\end{array}$ & Herbarium & Province & $\begin{array}{c}\text { Year } \\
\text { collected }\end{array}$ \\
\hline A. arequipensis Vog. & 1 & 3-NPOH & $\begin{array}{r}\text { Gómez-Sosa \& } \\
\text { Múlgura } 142\end{array}$ & SI, UTC & Tucumán & 1984 \\
\hline A. arnottianus (Gill.) Reiche & 1 & 3-NPOH & $\begin{array}{l}\text { J. Hunziker } \\
\text { et al. } 11189\end{array}$ & SI, UTC & Mendoza & 1985 \\
\hline $\begin{array}{l}\text { A. bergii Hieron. } \\
\text { A. bustillossii Clos. }\end{array}$ & $\begin{array}{l}2 \\
1\end{array}$ & $\begin{array}{l}\text { 3-NPOH } \\
\text { 3-NPOH }\end{array}$ & $\begin{array}{r}\text { Cordo 77-D-28 } \\
\text { Gómez-Sosa \& } \\
\text { Múlgura } 168\end{array}$ & $\begin{array}{l}\text { Herb. Cordo } \\
\text { SI, UTC }\end{array}$ & $\begin{array}{l}\text { Córdoba } \\
\text { Tucumán }\end{array}$ & $\begin{array}{l}1977 \\
1984\end{array}$ \\
\hline $\begin{array}{l}\text { A. carinatus (Hook. \& Arn.) } \\
\text { Reiche }\end{array}$ & 1 & 3-NPOH & $\begin{array}{l}\text { Cordo \& Ferrer } \\
77-D-12\end{array}$ & Herb. Cordo & Mendoza & 1977 \\
\hline $\begin{array}{l}\text { A. chamissonis (Vog.) Reiche } \\
\text { A. cruckshanksii (Hook. \& Arn.) } \\
\text { Griseb. }\end{array}$ & $\begin{array}{l}1 \\
1\end{array}$ & $\begin{array}{l}\text { 3-NPOH } \\
\text { 3-NPOH }\end{array}$ & $\begin{array}{l}\text { Gerling } 259 \\
\text { Marques \& } \\
\text { Gómez-Sosa } 54\end{array}$ & $\begin{array}{l}\text { SI } \\
\text { SI }\end{array}$ & $\begin{array}{l}\text { Mendoza } \\
\text { Mendoza }\end{array}$ & $\begin{array}{l}1907 \\
1985\end{array}$ \\
\hline A. crypticus Johnst. & Trace & 3-NPOH & $\begin{array}{c}\text { Gómez-Sosa \& } \\
\text { Múlgura } 232\end{array}$ & SI, UTC & Tucumán & 1984 \\
\hline A. cryptobotrys Johnst. & 1 & 3-NPOH & $\begin{array}{r}\text { Gómez-Sosa \& } \\
\text { Múlgura } 161\end{array}$ & SI, UTC & Tucumán & 1984 \\
\hline A. cuyanus Gómez-Sosa & 1 & 3-NPOH & Cordo \& Deloach & Herb. Cordo & Mendoza & 1978 \\
\hline A. distinens Macloskie & 2 & 3-NPOH & $\begin{array}{l}\text { Troncoso \& } \\
\text { Bacigalupo } 3059\end{array}$ & SI & Entre Ríos & 1981 \\
\hline A. domeykoanus (Phil.) Reiche & 1 & 3-NPOH & None & $\mathbf{K}$ & South America ${ }^{3}$ & 1927 \\
\hline A. famatinae Johnst. & 1 & 3-NPOH & $\begin{array}{l}\text { Cordo \& Runna- } \\
\text { cles } 77-\mathrm{D}-39\end{array}$ & Herb. Cordo & Jujuy & 1978 \\
\hline A. flavocreatus Johnst. & 1 & 3-NPOH & $\begin{array}{c}\text { Gómez-Sosa \& } \\
\text { Múlgura } 193\end{array}$ & SI, UTC & Tucumán & 1984 \\
\hline $\begin{array}{l}\text { A. garbancillo Cav. } \\
\text { A. hypsogenus Johnst. }\end{array}$ & $\begin{array}{c}\text { Trace } \\
1\end{array}$ & $\begin{array}{l}\text { 3-NPOH } \\
\text { 3-NPOH }\end{array}$ & $\begin{array}{l}\text { Kiesling } 4428 \\
\text { Cabrera et al. } \\
27426\end{array}$ & $\begin{array}{l}\text { SI } \\
\text { SI }\end{array}$ & $\begin{array}{l}\text { San Juan } \\
\text { Jujuy }\end{array}$ & $\begin{array}{l}1984 \\
1976\end{array}$ \\
\hline $\begin{array}{l}\text { A. joergensenii Johnst. } \\
\text { A. micranthellus Wedd. }\end{array}$ & $\begin{array}{l}0 \\
1\end{array}$ & $\begin{array}{c}\text { None } \\
\text { 3-NPOH }\end{array}$ & $\begin{array}{l}\text { Fabris } 6312 \\
\text { Ledingham \& } \\
\text { Cabezas }\end{array}$ & $\begin{array}{l}\mathbf{L P} \\
\text { NY }\end{array}$ & $\begin{array}{l}\text { Jujuy } \\
\text { Jujuy }\end{array}$ & $\begin{array}{l}1966 \\
1966\end{array}$ \\
\hline A. monticola Phil. & 0 & None & $\begin{array}{l}\text { Cabrera et al. } \\
31166\end{array}$ & SI & San Juan & 1979 \\
\hline A. palenae (Phil.) Reiche & 2 & $\begin{array}{l}\text { 3-NPOH \& } \\
\text { 3-NPA }\end{array}$ & $\begin{array}{l}\text { Cabrera et al. } \\
33089\end{array}$ & SI & Chubut & 1981 \\
\hline $\begin{array}{l}\text { A. palenae var. grandiflora Speg. } \\
\text { A. parodii Johnst. }\end{array}$ & $\begin{array}{c}1 \\
\text { Trace }\end{array}$ & $\begin{array}{l}\text { 3-NPOH } \\
\text { 3-NPOH }\end{array}$ & $\begin{array}{l}\text { Ruiz-Leal } 23914 \\
\text { Burkart } 10307\end{array}$ & $\begin{array}{l}\text { SI } \\
\text { SI }\end{array}$ & $\begin{array}{l}\text { Neuquén } \\
\text { Córdoba }\end{array}$ & $\begin{array}{l}1965 \\
1977\end{array}$ \\
\hline A. palagonicus (Phil.) Speg. & Trace & 3-NPOH & $\begin{array}{l}\text { Roig, TBPA } \\
2474\end{array}$ & SI & Santa Cruz & 1977 \\
\hline A. pauranthus Johnst. & 1 & 3-NPOH & $\begin{array}{l}\text { Cordo \& Run- } \\
\text { nacles 77-D-54 }\end{array}$ & Herb. Cordo & Catamarca & 1977 \\
\hline A. pehuenches Niederl. & 1 & 3-NPOH & $\begin{array}{l}\text { Marques \& } \\
\text { Gómez-Sosa } 58\end{array}$ & SI, UTC & Mendoza & 1985 \\
\hline A. peruvianus Vog. & Trace & 3-NPOH & $\begin{array}{r}\text { Gómez-Sosa \& } \\
\text { Múlgura } 166\end{array}$ & SI, UTC & Tucumán & 1984 \\
\hline $\begin{array}{l}\text { A. ruiz-lealii Johnst. } \\
\text { A. sanctae-crucis Speg. }\end{array}$ & $\begin{array}{c}0 \\
\text { Trace }\end{array}$ & $\begin{array}{c}\text { None } \\
\text { 3-NPOH }\end{array}$ & $\begin{array}{l}\text { Covas } 2140 \\
\text { Nicora } 8411\end{array}$ & $\begin{array}{l}\text { SI } \\
\text { SI }\end{array}$ & $\begin{array}{l}\text { Mendoza } \\
\text { Chubut }\end{array}$ & $\begin{array}{l}1943 \\
1982\end{array}$ \\
\hline A. tarijensis Wedd. & 1 & 3-NPOH & $\begin{array}{r}\text { Gómez-Sosa \& } \\
\text { Múlgura } 227\end{array}$ & SI & Tucumán & 1984 \\
\hline A. uniflorus DC. & Trace & 3-NPOH & $\begin{array}{r}\text { Gómez-Sosa \& } \\
\text { Múlgura } 212\end{array}$ & SI, UTC & Tucumán & 1984 \\
\hline A. vesiculosus Clos. & 2 & 3-NPOH & $\begin{array}{l}\text { J. Hunziker } \\
\text { et al. } 11304\end{array}$ & SI, UTC & Mendoza & 1985 \\
\hline
\end{tabular}

'Qualitative analysis: Trace equals 2 to $3 \mathrm{mg} \mathrm{NO} / \mathrm{g}$ of leaf

1 equals 4 to $8 \mathrm{mg} \mathrm{NO} / \mathrm{g}$ of leaf

2 equals 9 to $13 \mathrm{mg} \mathrm{NO} / \mathrm{g}$ of leaf

${ }^{2}$ Herbarium at the Biological Control of Weeds Research Laboratory, U.S. Dept. Agr., ARS, Bucnos Aires, Argentina.

${ }^{3}$ Astragalus domeykoanus is indigenous in the four southern provinces of Argentina: Neuquén, Rio Negro, Chubut, and Santa Cruz. 
cillo (sub $A$. unifultus L. Heritier) that were toxic by intravenous, intracardiac, and intraperitoneal injection to laboratory animals. Neither compound had previously been reported in toxic levels in Astragalus. Saponins have been isolated in Astragalus glycyphyllos L. and A. ammodytes Pall. (Gibbs 1974) but neither is known to be poisonous. Analyses for selenium, an element found in toxic concentrations in more than 20 species of North American Astragalus, have proved negative in Argentina (Burkhart 1952).

Several cases of poisoning by $\boldsymbol{A}$. pehuenches in Chubut Province in central Patagonia were ascribed to selenium accumulation by the plant (unpubl. medical reports of the Minister of Economy, Services and Public Works, Chubut Province, Argentina). The diagnosis of selenium poisoning was derived by comparing the toxic signs observed or described by local farmers with those described in the literature. No analyses of the plants were made to determine if selenium was in fact present, nor plants analyzed determine the presence or concentration of 3-NPOH, which is known to be present in $A$. pehuenches.

The syndromes of selenium and nitro poisoning are similar and both are characterized by loss of motor control, depression, grating of teeth, salivation, foaming at the nostrils, rapid and labored respiration, frequent urination, and impaired vision which causes the animal to stumble over small objects or to run into objects in its path (Rosenfeld and Beath 1964).

Giusti (1934) fed $A$. bergii as part of the diet to horses, pigs, sheep, and goats. Horses and pigs showed no toxic signs in 5 months of feeding, but 9 of 14 sheep died within 25 days and 6 of 8 goats died within 24 hours. $A$. bergii contains $3-\mathrm{NPOH}$ at levels that would produce these results, and this compound is much more toxic to ruminants than nonruminants.

Gallo (1979) reported toxic signs observed in livestock poisoned by $A$. pehuenches (sub $A$. bergii) were: nervousness, rigidity in walk, loss of sense of direction, lack of gregariousness, muscular incoordination, weight loss, general weakness, animals leaned against objects to keep from falling, and once the animal collapsed, it could not arise. Kidneys and liver were discolored but of normal consistency, and there was a decrease in percent hemoglobin.

The above toxic signs are similar to those described for poisoning by nitro-bearing species of Astragalus in North America (James et al. 1980) and an increase in methemoglobin is a constant finding.

Nitro compounds are very stable and the presence and type of compound can be determined with as little as $10 \mathrm{mg}$ of leaf from herbarium specimens up to 150 years old (Williams 1981). Nitro compounds occur primarily in the leaflets of Astragalus. The concentration of these compounds is usually highest when the plant is in bloom to early pod stage of growth, then drops as the plant approaches senescence (Williams and Norris 1969). Once the leaves turn brown and die, nitro concentration falls to nontoxic levels. Therefore, nitro levels for some species listed in Table 1 might have been higher had the plants been collected under optimum conditions.

Approximately $90 \%$ of the Argentine species examined synthesized nitro compounds. By contrast, only about $12 \%$ of the Old World and $52 \%$ of the North American species of Astragalus examined are known to be nitro-bearing (Williams 1981, Williams and Barneby 1977).

Livestock should be prevented from grazing nitro-bearing Astragalus. Medical treatment is largely ineffective. $\mathrm{NO}_{2} \mathrm{com}-$ plexes with ferrous hemoglobin and prevents its reoxygenation. The methemoglobin concentration in the blood of fatally poisoned animals may exceed $30 \%$. Prompt administration of methylene blue alleviates methemoglobinemia, but this treatment does not counteract the effects of 3-NPOH or 3-NPA which affect the portion of the brain that controls motor and automatic responses (Williams et al. 1969).

The $\mathrm{LD}_{50}$ of 3-NPOH, given orally in a single dose, is approximately $50 \mathrm{mg} \mathrm{NO} / \mathrm{kg}$ of body weight for sheep and $25 \mathrm{mg} \mathrm{NO} / \mathrm{kg}$ for cattle (Williams and James 1975 , Williams et al. 1969). Sublethal doses of nitro compounds affect the brain, lungs, spinal cord, heart, kidneys, and liver. Many of these changes are irreversible and once toxic signs have become pronounced, animals will never recover normal health even if they are removed to wholesome forage. Therefore, plants should be avoided until they have dried up, or they should be controlled chemically or mechanically. Herbicides that cause the plants to desiccate hasten their detoxication (Williams 1970).

Argentina lies between latitudes $22^{\circ}$ South and $55^{\circ}$ South, approximately the same distance in north latitude between Cuba and Hudson Bay. This area includes mountains, subtropic and temperate zones, and cold deserts similar to those found in the United States. Many species of Astragalus from Argentina, if introduced into the United States, might be adapted to similar ecological sites, particularly on the cold deserts, foothills, and mountains of the West. Because of the high incidence of species that synthesize nitro compounds that hydrolyze to 3-NPOH, all species of Astragalus from Argentina should be carefully evaluated for toxicological properties before any research and development lcading to their introduction and release is contemplated. Species that synthesize 3-NPOH should be excluded from introduction for any purpose because of their potential hazard to livestock.

\section{Summary and Conclusions}

The data indicate that aliphatic nitro compounds that hydrolyze to 3-NPOH are present in 27 species and 1 variety of Astragalus in Argentina. HCN was not detected in any species. We therefore conclude that 3-NPOH is the principal if not the sole toxic compound in poisonous species since (1) all species known to cause livestock losses synthesize toxic levels of 3-NPOH; (2) the toxicological and pathological signs described are similar to those described for nitro-bearing species of Astragalus in western North America; and (3) Astragalus bergii, A. distinens, and A. vesiculosus, species often associated with livestock losses in Argentina, synthesized 3-NPOH at the same concentration as A. emoryanus, a species that is known to cause extensive livestock losses in the United States.

\section{Literature Cited}

A.O.A.C. 1980. Official methods of analysis (13 Ed.) Association of Official Analytical Chemists. Washington, D.C.

Awschalom, M. 1928. Contribución al estudio del Astragalus unifultus L'Heritier (garbancillo). Publ. Lab. Quimica, Univ. Nac. de Tucumán, No. 1, 29 p. Buenos Aires.

Burkart, A. 1952. Las leguminosas Argentinas, silvestres y cultivadas, p. 272-279, ed. II, Acme Agency, S.R.L., Buenos Aires.

Gallo, G.G. 1979. Plantas tóxicas para el ganado en el cono sur de América. p. 76-79. Editorial Universitaria de Buenos Aires.

Gibbs. R.D. 1974. Chemotaxonomy of flowering plants, Vol. II. McGillQueen's University Press, Montreal.

Giusti, L. 1934. Experiencias sobre la acción fisiológica de la Wedelia glacua y del Astragalus bergii. Rev. Arg. Agr. 1:223-228.

Giusti, L. 1938. Plantas forrajeras cianogenéticas. Jornadas Agronómicas y Veterinarias de 1937, p. 43-49. Buenos Aires.

Gómez-Sosa, E. 1979. Las especies Sudamericanas del género Astragalus (Leguminosae). 1. Las especies Patagónicas Argentinas. Darwiniana 22:313-376.

Gómez-Sosa, E. 1984. Astragalus L. p. 175-206. In: M. Correa, Flora Patagónica, Parte IV b (Droseraceae a Leguminosae). Col. Científica del INTA, Buenos Aires.

James, L.F., W.J. Hartley, M.C. Williams, and K.R. Van Kampen. 1980. Field and experimental studies in cattle and sheep poisoned by nitrobearing Astragalus or their toxins. Amer. J. Vet. Res. 41:377-382.

Monticelli, J.V. 1938. Anotaciones fitogeográficas de la Pampa Central. Lilloa 3:344-346.

Rosenfeld, I., and O.A. Beath. 1964. Selenium. 441 p. Academic Press, New York.

Williams, M.C. 1970. Detoxication of timber milkvetch by $2,4,5-\mathrm{T}$ and silvex. J. Range Manage. 23:400-402.

Williams, M.C. 1981. Nitro compounds in foreign species of Astragalus. Weed Sci. 29:261-269. 
Williams, M.C. 1982. 3-Nitropropionic acid and 3-nitro-1-propanol in species of Astragalus. Can. J. Bot. 60:1956-1963.

Williams, M.C., and R.C. Barneby. 1977. The occurrence of nitro-toxins in North American Astragalus (Fabaceae). Brittonia 29:310-326.

Williams, M.C., and L.F. James. 1975. Toxicity of nitro-containing Astragalus to sheep and chicks. J. Range Manage. 28:260-263.

Williams, M.C., L.F. James, and B.O. Bond. 1979. Emory milkvetch (Astragalus emoryanus var. emoryanus) poisoning in chicks, sheep, and cattle. Amer. J. Vet. Res. 40:403-406.
Williams, M.C., and F.A. Norris. 1969. Distribution of miserotoxin in varieties of Astragalus miser Dougl. ex Hook. Weed Sci. 17:236-238.

Williams, M.C., F.A. Norris, and K.R. Van Kampen. 1970. Metabolism of miserotoxin to 3-nitro-1-propanol in bovine and ovine ruminal fluids. Amer. J. Vet. Res. 31:259-262.

Williams, M.C., K.R. Van Kampen, and F.A. Norris. 1969. Timber milkvetch poisoning in chickens, rabbits, and cattle. Amer. J. Vet. Res. 30:2185-2190. 